\title{
Crowdfunding projects of the academic community
}

\author{
MARTA TUTKO ${ }^{1}$ (iD https://orcid.org/0000-0002-8359-8081 \\ The Jagiellonian University in Kraków, Faculty of Management and Social \\ Communication, Institute of Economics, Finance and Management
}

\begin{abstract}
The goals of the paper are: (1) to examine to what extent is the academic community involved in creating their own or supporting other crowdfunding projects and (2) indicate the types of educational or scientific projects that are the most suitable for crowdfunding financing. The diagnostic survey method was applied. Questionnaires were completed by 314 full-time students and 34 academic teachers of the Institute of Economics, Finance and Management, of the Faculty of Management and Social Communication, at the Jagiellonian University in Krakow.

It can be assumed that the academic community is hardly involved at all in creating their own or slightly involved in supporting others' crowdfunding projects. The most proper for crowdfunding financing types of the projects are: (1) for the entire academic community: educational event and setting up and equipping the student area, (2) for students: learning foreign languages and purchase of materials for the study process, (3) for academic teachers: conducting an experiment and book publication.
\end{abstract}

Paper type: research article

Key words: crowdfunding, crowdfunding project, higher education, academic community.

\section{Introduction}

One of the challenges for academic communities (students and academic teachers) is insufficient financial resources for their activities, especially in the area of education and research. For this reason, the subject of alternative sources for funding

1 marta.tutko@uj.edu.pl 
higher education, undertaken in this paper, is important and valid. An example of an alternative way of financing these activities is crowdfunding - an idea combining financial services, social networks and the Internet. Crowdfunding might support financing of creative and innovative projects, which are financed by many small payments made by individuals (i.e. a crowd) concerned.

Crowdfunding can be used by academic communities to raise funds for a variety of projects. It can be an important source of financing educational projects, such as: payment of tuition fees, scholarships, raising funds for a computer lab, funding new athletic team uniforms, support for the school library, funding for educational events and many others (Solemon, Ariffin, Din, \& Anwar, 2013, p. 2069). Also, the sphere of scientific research is an area where social funding might be used. For example, as part of all the competitions announced by the National Science Center in Poland in 2017, more than 10,000 applications were submitted. The total success rate was 29\% (Narodowe Centrum Nauki, 2018, p. 10). This means that (probably) $71 \%$ of the projects have not been and will never be realized. Crowdfunding can be an alternative source of financing for such projects, and as Gates stated, "This solution helps close the gap for potential and promising, but unfunded projects" (Experiment, n.d.). Researchers can apply for funds to conduct experiments, pilot studies, participate in scientific conferences, publish publications, especially books (Tutko, 2018, p. 213).

The above premises define the scientific goals of the paper, which are: (1) to examine to what extent is the academic community is involved in creating their own or supporting other crowdfunding projects and (2) indicate the types of educational or scientific projects that are the most suitable for crowdfunding financing. To realize the goals of this study, opinions of students and academic teachers of the Institute of Economics, Finance and Management (IEFM), of the Faculty of Management and Social Communication, at the Jagiellonian University in Kraków, Poland, were collected. The diagnostic survey method was chosen and the questionnaire technique was selected.

\section{Crowdfunding project and it's elements}

Although works on crowdfunding have been created for some years (Awdziej, Krzyżanowska, \& Tkaczyk, 2016; Dziuba, 2012; Forbes \& Schaefer, 2017; Freedman \& Nutting, 2015; Kozioł-Nadolna, 2015; Król, 2013; Larralde \& Schwienbacher, 2012; Lenart-Gansiniec, 2016, 2017, 2018; Méric, Maque, \& Brabet, 2016; Pieniążek, 2014), it is still a little-known area of research and therefore it "finds itself in a juvenile state of scientific research" (Kraus, Richter, Brem, Cheng, \& Chang, 2016, p. 15).

Larralde and Schwienbacher (2012, p. 3) define crowdfunding as the "financing of a project or a venture by a group of individuals instead of professional parties" 
usually taking place online, through dedicated platforms, for the provision of financial resources in order to support initiatives for specific purposes. Forbes and Schaefer $(2017$, p. 399) note that crowdfunding exists in many forms and propose its' generalized definition: "the process of taking a project or business, in need of investment, and asking a large group of people, which is usually the public, to supply this investment." Kraus et al. (2016, p. 15) suggest that various definitions of crowdfunding exist, but none of them have received scientific acceptance. After analysing many definitions proposed by different authors they noticed that there are common elements found in many definitions. They include: "crowd-funding focuses on raising financial funding from the public, represented by a group of people, using specific internet-based platforms" (Kraus, et al., 2016, p. 15).

Also Dziuba (2012, pp. 85-86), writing about crowdfunding, points out that it is "a process carried out in an online environment, activated through an open submission of an offer, consisting on raising financial funding from a potentially huge number of dispersed participants ('crowd')." This definition, including common elements found by Kraus et al. (2016), has been adopted in this work.

Crowdfunding contains three different methods of raising funds: (1) the donations model (in which funders provide money for a project for no return or in return for some form of non-financial reward), (2) the lending model (where funders provide money as a loan, that needs to be repaid with interest) and (3) the investment model (in which funders provide money in return for a share of profits) (The Association for UK Interactive Entertainment, 2012, p. 2).

In order to define what a crowdfunding project is, one should first look at the definition of the project. In this paper the definition was adopted from Wysocki and McGary (2003, p. 3) that "a project is a sequence of unique, complex, and connected activities having one goal or purpose and that must be completed by a specific time, within budget, and according to specification."

Project activities are unique. Wysocki and McGary (2003, p. 7) point out that the project has never existed before and will never be repeated in the same conditions. At the same time, the authors pay attention to the following parameters in each project:

1. Scope.

2. Quality.

3. Cost.

4. Time.

5. Resources.

These parameters are interdependent - changing one of them may involve changing the others, thus restoring the project's balance.

On the basis of the above definitions of crowdfunding and the project, an attempt can be made to determine what a crowdfunding project is. Based on the definitions of Wysocki and McGary (2003), and Dziuba (2012), a crowdfunding project is a sequence of unique, complex, and connected activities carried out in an 
online environment, whose goal is raising financial funding from a potentially huge number of dispersed participants, and that must be completed by a specific time, within budget, and according to specification.

The aim of developing a crowdfunding project is to obtain sponsors (a huge number of dispersed participants, crowd) that will enable its implementation, via financial support. In order to achieve this goal, the crowdfunding project should contain the following elements (Tutko, in print):

1. A project title, that will encourage people to get acquainted with the project.

2. The financial goal and budget of the project.

3. Information about the project (purpose, motivation), which indicates its attractiveness.

4. An action plan, that should convince sponsors that the project is feasible and realistic.

5. Information about prizes for financial support.

6. Visual presentations (graphics, photos, videos).

7. Creating dedicated accounts in social media, which allows a wide audience to be reached.

8. A project website, which allows funders to get detailed information about the project.

To sum up the above terminological considerations, it is worth quoting Mollick's opinion (2014, p. 2), that crowdfunding success is linked to project quality, because projects that are of a higher quality are more likely to be funded and depends on a number of friends on online social networks, which are also associated with success.

\section{Research methodology}

The subject of discussion in this study will be a donations crowdfunding model, which is most adequate to use by academic communities to realize educational or scientific projects.

This study raises the following two research questions:

a) To what extent is the academic community involved in crowdfunding projects by creating their own or supporting others'?

b) Which types of the educational or scientific projects are the most suitable for crowdfunding financing?

To answer the research questions, the diagnostic survey method was chosen and the questionnaire technique was selected. The questionnaire included questions concerning crowdfunding platforms known to the academic community, involvement of the academic community in crowdfunding projects and the types of projects suitable for crowdfunding financing. It was also comprised of the respondent's 
particulars (at the end) and a filtering question "Did you know the term crowdfunding before receiving this survey?" (at the beginning of the questionnaire). ${ }^{2}$

Knowledge about the involvement of the academic community in crowdfunding projects and the types of projects suitable for crowdfunding financing was gathered on the basis of selected representative samples characterizing the general statistical population. These samples were full-time students and academic teachers of the Institute of Economics, Finance and Management (IEFM), of the Faculty of Management and Social Communication, at the Jagiellonian University in Krakow, Poland.

There are 1,317 full-time first-cycle and second-cycle students studying Economics and Management. Details regarding students are presented in the Table 1.

Table 1 The number of full-time students in the IEFM

\begin{tabular}{|l|c|c|c|}
\hline & $\begin{array}{c}\text { Number of first-cycle } \\
\text { students }\end{array}$ & $\begin{array}{c}\text { Number of second-cycle } \\
\text { students }\end{array}$ & Total \\
\hline Field of study: Economics & 228 & 316 & 544 \\
\hline Field of study: Management & 300 & 473 & 773 \\
\hline Total & 528 & 789 & 1317 \\
\hline
\end{tabular}

Source: own work based on information from the secretariat of the IEFM received on 12.03.2018.

In the case of students, an auditorium survey, completed during lectures, was carried out, which allowed to capture a large group of respondents. 314 students properly completed questionnaires, which is $23.8 \%$ of all full-time students at IEFM. A questionnaire was also given to 59 academic teachers employed in the IEFM. 34 completed questionnaires were received, which is $57.6 \%$.

The application of the filtering question allowed to reject 61 questionnaires, because respondents indicated that they did not know the term crowdfunding. Finally, 260 questionnaires filled out by students, and $24^{3}$ completed by academic teachers were analysed. The survey was conducted in the first quarter of the year 2018.

This study was preceded by a pilot study, carried out in 2017 .

${ }^{2}$ Only a part of the data obtained in the survey was used to write this article. The other part was used to write another article: Tutko (in print).

${ }^{3}$ In the case of academic teachers 3 incorrectly completed surveys were rejected. 


\section{Research results}

3.1. Academic community involvement in crowdfunding projects

First, respondents were asked to indicate which of the crowdfunding platforms are known to them. They had the opportunity to indicate any number of crowdfunding platforms from the list of answers, which contained 19 platform names (in addition, the list contained the answers: "none of these" and "other, what?"). Their responses are presented in the Table 2.

Table 2 Crowdfunding platforms known to the academic community

\begin{tabular}{|c|c|c|c|c|}
\hline \multirow[t]{2}{*}{$\begin{array}{l}\text { Name of the } \\
\text { platform }\end{array}$} & \multicolumn{2}{|c|}{$\begin{array}{l}\text { Indications of students } \\
\qquad(\mathrm{n}=260)\end{array}$} & \multicolumn{2}{|c|}{$\begin{array}{l}\text { Indications of academic teachers } \\
\qquad(\mathrm{n}=24)\end{array}$} \\
\hline & Number & $\%$ & Number & $\%$ \\
\hline PolakPotrafi & 119 & 45.77 & 14 & 58.33 \\
\hline Beesfund & 4 & 1.54 & 1 & 4.17 \\
\hline Siepomaga & 106 & 40.77 & 10 & 41.67 \\
\hline Crowdangels & 17 & 6.54 & 2 & 8.33 \\
\hline Fans4club & 15 & 5.77 & 1 & 4.17 \\
\hline Megatotal & 3 & 1.15 & 0 & 0.00 \\
\hline Odpalprojekt & 17 & 6.54 & 3 & 12.50 \\
\hline Wspieramkulture & 51 & 19.62 & 3 & 12.50 \\
\hline Wspieram.to & 46 & 17.69 & 7 & 29.17 \\
\hline Experiment & 21 & 8.08 & 0 & 0.00 \\
\hline Kickstarter & 85 & 32.69 & 6 & 25.00 \\
\hline Indiegogo & 33 & 12.69 & 3 & 12.50 \\
\hline StayClassy & 10 & 3.85 & 1 & 4.17 \\
\hline FirstGiving & 4 & 1.54 & 0 & 0.00 \\
\hline RocketHub & 5 & 1.92 & 2 & 8.33 \\
\hline Classy & 7 & 2.69 & 0 & 0.00 \\
\hline Crowdrise & 33 & 12.69 & 2 & 8.33 \\
\hline GoFundMe & 20 & 7.69 & 1 & 4.17 \\
\hline Razoo & 7 & 2.69 & 0 & 0.00 \\
\hline None of these & 52 & 20.00 & 7 & 29.17 \\
\hline Other & 10 & 3.85 & 1 & 4.17 \\
\hline
\end{tabular}


Less than $30 \%$ of academic teachers and $20 \%$ of students said they were not familiar with any names of crowdfunding platforms that were on the list of proposed answers. Ten students and one academic teacher indicated additional platform names, such as: Patronite, Zrzutka, Patreon.

Crowdfunding platforms best known to students are: PolakPotrafi, Siepomaga, Kickstarter and Wspieramkulture. The teachers demonstrated almost the same opinion, as they ticked PolakPotrafi, Siepomaga, Wspieram.to and Kickstarter. On the other hand, in the opinion of the surveyed students, the least-known platforms are Megatotal, Beesfund and FirstGiving, while the teachers do not know the platforms: Megatotal, Experiment, FirstGiving, Classy and Razoo.

The respondents were also asked if they have ever financially supported a crowdfunding project. $15 \%$ of students and $50 \%$ of academic teachers gave positive responses to this question. Only $3 \%$ of students and none of the teachers used crowdfunding to finance their projects.

\subsection{The most suitable for crowdfunding financing types of projects}

For the purpose of this study, different types of projects have been identified which can be financed through crowdfunding, and then they were divided into three groups, depending on who the beneficiaries of the project were (Figure 1).

\begin{tabular}{|c|c|c|}
\hline $\begin{array}{c}\text { Projects whose } \\
\text { beneficiaries are the entire } \\
\text { academic community }\end{array}$ & $\begin{array}{l}\text { Projects whose } \\
\text { beneficiaries are individual } \\
\text { academic teachers }\end{array}$ & $\begin{array}{l}\text { Projects whose } \\
\text { beneficiaries are } \\
\text { individual students }\end{array}$ \\
\hline $\begin{array}{l}\text { - setting up the HEl's } \\
\text { laboratory } \\
\text { - educational event } \\
\text { (e.g. a science festival) } \\
\text { - cultural event (e.g. a concert) } \\
\text { - organization of the graduates' } \\
\text { meeting } \\
\text { - organization of the jubilee } \\
\text { - organization of the } \\
\text { conference } \\
\text { - maintaining and renovating } \\
\text { HEl's facilities } \\
\text { - functioning of the scientific } \\
\text { club } \\
\text { - setting up and equipping the } \\
\text { student area } \\
\text { - functioning of the publishing } \\
\text { house }\end{array}$ & $\begin{array}{l}\text { - conducting an experiment } \\
\text { - pilot studies } \\
\text { - scientific research } \\
\text { - learning foreign languages } \\
\text { - participation in a course } \\
\text { - participation in a scientific } \\
\text { conference } \\
\text { - book publication } \\
\text { - purchase of books and } \\
\text { databases } \\
\text { - purchase of a computer, } \\
\text { software }\end{array}$ & $\begin{array}{l}\text { - payment of tuition fees } \\
\text { - renting an apartment } \\
\text { - learning foreign languages } \\
\text { - participation in a course } \\
\text { - participation in a scientific } \\
\text { conference } \\
\text { - research as part of the } \\
\text { diploma thesis } \\
\text { - purchase of books, } \\
\text { textbooks } \\
\text { - purchase of materials and } \\
\text { equipment for the study } \\
\text { process } \\
\text { - purchase of a computer, } \\
\text { software }\end{array}$ \\
\hline $\begin{array}{l}\text { - operation of the scholorship } \\
\text { fund }\end{array}$ & & \\
\hline
\end{tabular}

Figure 1. Types of crowdfunding projects. 
Students and academic teachers were asked which of the above projects are the most suitable for crowdfunding financing.

The first question was directed to both groups, in the same wording, and it concerned the projects which are the most suitable for financing using crowdfunding, and that are beneficiary to the entire academic community. Each respondent was asked to select 5 projects from the list and mark the most suitable one. The answers obtained on the basis of five given responses are shown in Table 3.

Table 3 Types of crowdfunding projects beneficiary to the entire academic community

\begin{tabular}{|c|c|c|c|c|}
\hline \multirow[t]{2}{*}{ Type of crowdfunding project } & \multicolumn{2}{|c|}{$\begin{array}{l}\text { Indications of students } \\
\qquad(\mathrm{n}=257)\end{array}$} & \multicolumn{2}{|c|}{$\begin{array}{c}\text { Indications of academic } \\
\text { teachers }(n=23)\end{array}$} \\
\hline & Number & $\%$ & Number & $\%$ \\
\hline Setting up the HEI's laboratory & 155 & 60.31 & 8 & 34.78 \\
\hline Educational event & 175 & 68.09 & 20 & 86.96 \\
\hline Cultural event & 139 & 54.09 & 16 & 69.57 \\
\hline Organization of the graduates' meeting & 50 & 19.46 & 10 & 43.48 \\
\hline Organization of the jubilee & 37 & 14.40 & 7 & 30.43 \\
\hline Organization of the conference & 92 & 35.80 & 9 & 39.13 \\
\hline Maintaining and renovating HEI's facilities & 126 & 49.03 & 4 & 17.39 \\
\hline Functioning of the scientific club & 116 & 45.14 & 14 & 60.87 \\
\hline Setting up and equipping the student area & 167 & 64.98 & 13 & 56.52 \\
\hline Functioning of the publishing house & 105 & 40.86 & 5 & 21.74 \\
\hline Operation of the scholarship fund & 122 & 47.47 & 9 & 39.13 \\
\hline Other & 1 & 0.39 & 1 & 4.35 \\
\hline
\end{tabular}

In the opinion of academic teachers, the most relevant project types for crowdfunding financing, which are beneficiary to the entire academic community, are: educational event, cultural event, functioning of the scientific club and setting up and equipping the student area. The answers given by the students were very similar. Representatives of this group most often indicated: educational event, setting up and equipping the student area, setting up the HEI's laboratory and cultural event. So to sum up, the three most frequently indicated by both studied groups types of the projects, are: educational event, setting up and equipping the student area and cultural event.

Students and academic teachers were also asked to mark the most suitable type of the project, as one of the five chosen. As a result of the analysis of their answers, both groups most frequently indicated the same types of projects, namely: setting up the HEI's laboratory, educational event and setting up and equipping the student area. 
Comparing the above results, obtained in two different ways, it can be seen that projects which are the most suitable for financing using crowdfunding, and that are beneficiary to the entire academic community, are: educational event and setting up and equipping the student area.

According to the surveyed students, projects that are the least appropriate for financing using crowdfunding are organization of: the conference, the graduates' meeting and the jubilee, whereas from teachers' opinion it appears that these are: organization of the jubilee, functioning of the publishing house and maintaining and renovating higher education institution's (HEI) facilities.

Two questions were asked to students and academic teachers to solve a research problem. In the case of the second inquiry, each group received a different question. The students spoke about educational projects, while the teachers gave opinions on projects related to the sphere of science. As previously, each respondent was asked to select five projects from the list and mark the most suitable one. The answers obtained on the basis of five given responses are shown in Table 4.

Table 4 Types of crowdfunding projects beneficiary to students and academic teachers

\begin{tabular}{|l|c|c|l|l|c|c|}
\hline \multicolumn{4}{|c|}{ Students responses (n=257) } & \multicolumn{3}{c|}{ Academic teachers responses (n 21) } \\
\hline Type of crowdfunding project & Number & $\%$ & Type of crowdfunding project & Number & $\%$ \\
\hline Payment of tuition fees & 87 & 33.85 & Conducting an experiment & 19 & 90.48 \\
\hline Renting an apartment & 79 & 30.74 & Pilot studies & 17 & 80.95 \\
\hline Learning foreign languages & 204 & 79.38 & Scientific research & 11 & 52.38 \\
\hline Participation in a course & 196 & 76.26 & Learning foreign languages & 3 & 14.29 \\
\hline Participation in a conference & 113 & 43.97 & Participation in a course & 10 & 47.62 \\
\hline $\begin{array}{l}\text { Research as part of diploma } \\
\text { thesis }\end{array}$ & 173 & 67.32 & Participation in a conference & 11 & 52.38 \\
\hline Purchase of books & 139 & 54.09 & Book publication & 18 & 85.71 \\
\hline $\begin{array}{l}\text { Purchase of materials for the } \\
\text { study process }\end{array}$ & 178 & 69.26 & $\begin{array}{l}\text { Purchase of books and data- } \\
\text { bases }\end{array}$ & 13 & 61.90 \\
\hline $\begin{array}{l}\text { Purchase of a computer, } \\
\text { software }\end{array}$ & 116 & 45.14 & $\begin{array}{l}\text { Purchase of a computer, } \\
\text { software }\end{array}$ & 2 & 9.52 \\
\hline
\end{tabular}

The projects, which are most suitable for financing based on crowdfunding, and that are beneficiary to students and academic teachers, are also presented in the Figures 2 and 3. 


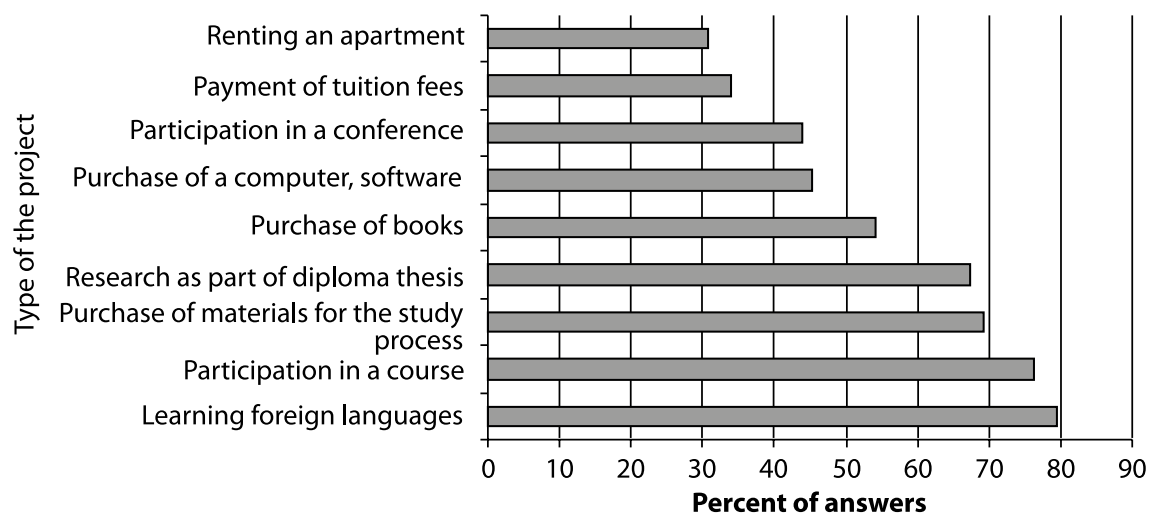

$\square$ Students

Figure 2. Types of crowdfunding projects beneficiary to students.

In the students' opinion, the types of projects that are more suited to crowdfunding financing are: learning foreign languages, participation in a course and purchase of materials for the study process. In turn those that are least suitable for this, are: participation in a conference, payment of tuition fees and renting an apartment.

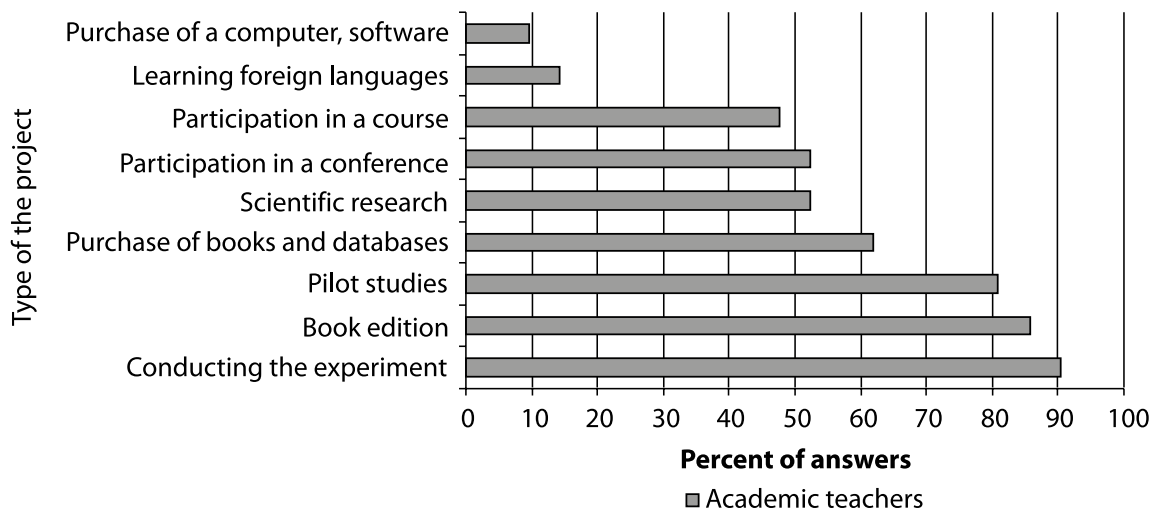

Figure 3. Types of crowdfunding projects beneficiary to academic teachers. 
Meanwhile, academic teachers expressed their opinion that the projects that will be the most appropriate for crowdfunding financing are: conducting an experiment, book publication and pilot studies. Those projects that should rather not be financed from this source are: participation in a course, learning foreign languages and purchase of a computer and software.

Students and academic teachers were also questioned about the most suitable type of project, as one of the five chosen. Students marked learning foreign languages, research as part of diploma thesis and purchase of materials for the study process. Compared to the previously presented results, it can be noticed that two types of projects were repeated in their statements: learning foreign languages and purchase of materials for the study process.

Using a similar approach as before, also the teachers, asked to indicate one of the five projects, stated: conducting the experiment, book publication and participation in a course. The two most frequently repeated types of projects, having regard to both approaches, are: conducting the experiment and book publication.

\section{Conclusions}

The first research question raised in the paper concerned the extent, to which is the academic community involved in creating their own or supporting others' crowdfunding projects.

Knowledge of crowdfunding platforms was analysed first. The most frequently indicated names of these platforms, by students and academic teachers of IEFM at the same time, are PolakPotrafi, Siepomaga and Kickstarter. Two of them are platforms operating only in Poland, while the third one is American. It is astonishing that academic teachers do not know the Experiment platform, which is dedicated to higher education institutions, as it allows scientists to publish information about research projects in order to obtain funds for their implementation.

The research shows that teachers support financially crowdfunding projects more often than students do. Only a small percentage of students and none of the teachers declared that they had created their own project. Therefore, based on the opinions expressed by IEFM representatives, it can be concluded that the academic community is hardly involved at all in creating their own or slightly involved in supporting others' crowdfunding projects. Hence, it is possible to propose a recommendation, that both groups could benefit from financing their projects through crowdfunding and that is why it is worth utilizing this form of alternative financing.

The second research question posed in the article referred to the projects, which are the most suitable for crowdfunding financing in the higher education area. For the purpose of this study, 29 types of potential projects have been identified. These types of the projects were divided into three groups, depending on who 
the beneficiaries of the project are: (1) the entire academic community, (2) individual academic teachers and (3) individual students.

In the opinion of surveyed academic teachers and students together, the two most relevant project types for crowdfunding financing, which are beneficiary to the entire academic community, are: educational event and setting up and equipping the student area. Students of IEFM think, that the most appropriate educational projects are: learning foreign languages and purchase of materials for the study process. Consecutively, academic teachers expressed their opinion that the scientific projects that will be the most proper are: conducting an experiment and book publication.

In each of the three groups of projects, the two types most frequently indicated by the respondents were presented above. This list may be a recommendation for students and academic teachers, but also for HEI's authorities, in which areas of education and research it is worth to (1) consider the creation of a crowdfunding project and (2) attempt to obtain funds for it's implementation by means of crowdfunding.

Based on the considerations presented in this article, the next research question arises, whether students and academic teachers from other Polish HEIs also present similar reviews, but this issue would require research on a wider scale, involving representatives from other HEIs.

\section{References}

Awdziej, M., Krzyżanowska, M., \& Tkaczyk, J. (2016). Motywowanie do współtworzenia wartości - rozważania na przykładzie platformy crowdfundingowej „Polakpotrafi.pl”. Nierówności Społeczne a Wzrost Gospodarczy, 45(1/2016), 41-49.

Dziuba, D. (2012). Rozwój systemów crowdfundingu - modele, oczekiwania i uwarunkowania. Problemy Zarządzania, 10(3), 83-103.

Experiment (n.d.). Retrieved from: https://experiment.com/ [accessed: 15.10.2018].

Forbes, H., \& Schaefer, D. (2017). Guidelines for successful crowdfunding. Procedia CIRP, 60, 398-403. Retrieved from: https://www.sciencedirect.com/science/article/pii/ S2212827117301178 [accessed: 4.10.2018].

Freedman, D.M., \& Nutting, M.R. (2015). Equity Crowdfunding for Investors: A Guide to Risks, Returns, Regulations, Funding Portals, Due Diligence, and Deal Terms. Hoboken, New Jersey: Wiley \& Sons.

Kozioł-Nadolna, K. (2015). Crowdfunding jako źródło finansowania innowacyjnych projektów. Zeszyty Naukowe Uniwersytetu Szczecińskiego. Finanse, Rynki Finansowe, Ubezpieczenia, (73/854), 671-683.

Kraus, S., Richter, C., Brem, A., Cheng, C., \& Chang, M. (2016). Strategies for reward-based crowdfunding campaigns. Journal of Innovation \& Knowledge, 1(1), 13-23.

Król, K. (2013). Crowdfunding. Od pomysłu do biznesu, dzięki społeczności. Warszawa: Crowdfunding.pl.

Larralde, B., \& Schwienbacher, A. (2012). Alternative types of entrepreneurial finance. In D. Cumming (ed.), The Oxford Handbook of Entrepreneurial Finance. Oxford: Oxford University Press. 
Lenart-Gansiniec, R. (2016). Crowd capital: conceptualisation attempt. International Journal of Contemporary Management, 15(2), 29-57.

Lenart-Gansiniec, R. (2017). Zaufanie a crowdsourcing w organizacjach publicznych. Organizacja i Kierowanie, 2(176), 229-240.

Lenart-Gansiniec, R. (2018). Crowdsourcing: analiza semantyczna. Przedsiębiorczość i Zarzadzanie, 19(6, part 2), 105-118.

Méric, J., Maque, I., \& Brabet, J. (2016). International Perspectives on Crowdfunding: Positive, Normative and Critical Theory. Bingley (UK): Emerald Group Publishing Limited.

Mollick, E. (2014). The dynamics of crowdfunding: An exploratory study. Journal of Business Venturing, 29(1), 1-16.

Narodowe Centrum Nauki (2018). Statystyki konkursów 2017. Kraków: Narodowe Centrum Nauki. Retrieved from: https://ncn.gov.pl/sites/default/files/pliki/statystyki/NCN_statystyki_2017.pdf [accessed: 4.10.2018].

Pieniążek, J. (2014). Najnowsze trendy i kierunki rozwoju finansowania społecznościowego. Marketing Instytucji Naukowych i Badawczych, 13(3), 3-18.

Solemon, B., Ariffin, I., Din, M., \& Anwar, R. (2013). A review of the uses of crowdsourcing in higher education. International Journal of Asian Social Science, 3(9), 2066-2073.

The Association for UK Interactive Entertainment (2012). UKIE. Crowd Funding Report: A Proposal to Facilitate Crowd Funding in the UK. London: The Association for UK Interactive Entertainment.

Tutko, M. (2018). Zastosowanie crowdfundingu w szkolnictwie wyższym. Zarządzanie Publiczne, 2(42), 205-215.

Tutko, M. (in print). The use of crowdfunding in entrepreneurship education in higher education institutions.

Wysocki, R.K., \& McGary, R. (2003). Effective Project Management. Traditional, Adaptive, Extreme ( $3^{\text {rd }}$ edition). Indianapolis, Indiana: Wiley Publishing.

\section{Note about the Author}

Marta Tutкo Ph.D. - is assistant professor at the Institute of Economics, Finance and Management, at the Faculty of Management and Social Communication, at the Jagiellonian University in Krakow, Poland. She is a graduate of the University of Economics in Krakow and the Jagiellonian University (she holds a $\mathrm{PhD}$ degree in economics in the discipline of management science). Her scientific and research interests include quality management of education and management in higher education institutions. 
